\title{
Clientele Served and Extension Functions Emphasized by the Extension Personnel of Extension Organizations
}

\author{
H.S. Sathish ${ }^{1 *}$, D.M. Chandargi ${ }^{2}$ and V.B. Wali ${ }^{3}$ \\ ${ }^{1}$ (Agril. Extension), Diploma (Agri.) College, AHRS, Kathalagere, India \\ ${ }^{2}$ (Students Welfare), UAS, Raichur - 584104, Karnataka, India \\ ${ }^{3}$ Department of Agricultural Statistics, College of Agriculture, Raichur - 584104, \\ Karnataka, India \\ *Corresponding author
}

\begin{tabular}{|c|}
\hline Keywords \\
\hline $\begin{array}{l}\text { Clientele, Krishi Vigyan } \\
\text { Kendras, Public } \\
\text { Extension Organizations, } \\
\text { Raita Samparka Kendras }\end{array}$ \\
\hline Article Info \\
\hline $\begin{array}{l}\text { Accepted: } \\
20 \text { April } 2018 \\
\text { Available Online: } \\
10 \text { May } 2018\end{array}$ \\
\hline
\end{tabular}

A B S T R A C T

A study was conducted to know the clientele served and type of extension functions emphasized by the extension personnel of public extension organizations in Hyderabad Karnataka region of Karnataka during 2013-14. A sample of 38 extension personnel from Krishi Vigyan Kendras under University of Agricultural Sciences, Raichur and 38 extension personnel from Raita Samparka Kendras under Karnataka State Department of Agriculture were selected for the study. The data was collected from the respondents using structured interview schedule developed for the study. The collected data was analyzed using appropriate statistical tools. The results of the study revealed that, majority of the extension personnel in Krishi Vigyan Kendras (52.63 \%) and Raita Samparka Kendras $(42.11 \%)$ belonged to medium to low satisfaction category with respect to facilities and resources availability in the organization. Over one third (36.84\%) of the extension personnel of Krishi Vigyan Kendras belonged to high satisfaction category with respect to communication in the organization and In case of Raita Samparka Kendras, higher percentage $(44.74 \%)$ of the extension personnel belonged to medium level of communication satisfaction category. Majority $(47.37 \%)$ of the extension personnel in both the extension organizations belonged to medium level of co-ordination. Youth farmers in case of Krishi Vigyan Kendras and small-scale subsistence farmers in case of Raita Samparka Kendras were the important group of clientele targeted. Transfer of technology is the most important extension function emphasized by both extension organizations. Hence extension organizations should emphasize and prioritize capacity building and empowerment of farmers, youth and women empowerment and entrepreneurship development.

\section{Introduction}

Worldwide, agricultural extension is the key instrument for the agricultural development process both in terms of technology transfer and human resource development.
Agricultural extension is a function of providing situational and need based knowledge and skills to rural people who are involved in traditional agriculture in nonformal situation. Various organizations are involved in providing agricultural extension 
services to farming community in India. Over the years, the number of organizations providing agricultural extension services is increasing and these organizations vary greatly in their activities and approaches depending on their goal, finance and manpower.

The major agricultural extension service providers are, Public agricultural extension service providers includes line departments of the state government like Department of agriculture, horticulture, animal husbandry etc, first line extension system of Directorate of Extension and other wings of State Agricultural Universities, various research units of ICAR, Co-operatives and commodity boards like rubber board and coffee board, farmers associations and producers' cooperatives and marketing board.

Private agricultural extension service providers: includes input supply companies like seeds, fertilizers, chemicals and farm machinery, Agro processing units, private consultants, Agri clinics and agri business centers, input dealers and print media. Nongovernmental organizations includes NGOs working in the area of agriculture and rural development and others including autonomous agencies in specific areas and crops, banks through their field officers and internet.

Over the years, number of agencies providing agricultural extension services is increasing resulting in increasing the opportunity to reach greater number of farmers scattered across the country. The need for agricultural extension and rural information is likely to intensify in future. In much of the world, the agriculture faces the challenge of keeping pace with rapidly increasing population with fewer reserves of potentially cultivable land.

Different extension organizations concentrate on different clientele based on their objectives/ goal, availability of resources and manpower and operational area. There is a need to study and know the different clientele groups concentrated by the extension organizations and also main extension functions emphasized by them in order to formulate suitable extension strategies for the benefit of farming community in future and to reform and reorient the extension system.

With this background the present study was conducted with an objective to know the different clientele served and extension functions prioritized by the extension organizations.

\section{Materials and Methods}

The present study was conducted in Raichur, Gulbarga, Bidar, Yadgir, Koppal and Bellary districts of Karnataka state during 2013-14. The districts coming under the judistriction of University of Agricultural Sciences, Raichur was the criterion in selection. Expost-facto research design was used in the present investigation.

The extension personnel working in Krishi Vigyan Kendras (KVKs) coming under the judistriction of UAS Raichur and extension personnel working in Raita Samparka Kendras (RSKs) were selected purposively. From each organization 38 extension personnel were selected.

The sample size was restricted to 38 because of availability of extension personnel in KVKs at the time of investigation was 38. Extension personnel from RSKs were selected from six districts using proportionate random sampling. Thus the sample for the study constituted 76 extension personnel. The data was collected from the extension personnel by personally distributing interview schedule. The collected data was analyzed using appropriate statistical tools and techniques. 


\section{Results and Discussion}

Facilities and resources availability in the extension organizations

It was evident from table 1 that, majority $(52.63 \%)$ of the extension personnel in the Krishi Vigyan Kendras belonged to medium level of satisfaction towards facilities and resources. Whereas, in case of Raita Samparka Kendras, majority $(42.11 \%)$ of the extension personnel belonged to low level of satisfaction. This shows that the respondents had less to medium facilities to carry out routine extension activities which need to be taken care. It was also revealed during the study that, majority of the extension personnel of public extension organizations expressed satisfaction towards input supplies, providing demonstration equipment, office supplies, supply procedure and storage facility (Table $2)$. The extension personnel were having limited freedom to purchase or acquire required facilities and resources. These could be probable reasons for medium to low satisfaction of extension personnel towards facilities and resources at work. Mann Whitney $U$ test also exhibited significant difference between extension personnel of both extension organizations.

The results are in line with the results obtained by Sandika (2006), Nagananda et al., (2006) and Debnath and Saravanan (2014).

\section{Communication}

With regard to communication aspects in the organization it could be seen from table 3 that, well over one third $(36.84 \%)$ of the extension personnel of Krishi Vigyan Kendras belonged to high satisfaction category. In case of Raita Samparka Kendras, higher percentage (44.74 $\%$ ) of the extension personnel belonged to medium level of communication satisfaction category.
It was evident from the above results that, majority of the extension personnel of public extension organizations belonged to medium to high satisfaction category with respect to communication aspects in the organization.

It might be due to good coordination among the superiors and subordinates, timely and required replay from the higher authorities and also use of proper communication channels by the higher authority in delivering messages. The results are in conformity with the results obtained by Debnath and Saravanan (2014) i.e., half of the extension personnel expressed medium level of satisfaction towards communication in the organization.

Item wise analysis of communication presented in table 4 revealed that, extension personnel of Krishi Vigyan Kendras expressed high satisfaction towards timely and required replies from higher ups (I rank) followed clear and complete message from higher ups (II rank), communication language used (III rank) and method of communication employed by higher ups (IV rank). The extension personnel of the Raita Samparka Kendras expressed high satisfaction towards timely information regarding programmes from higher ups (I rank), timely and required replies from higher ups (I rank) and communication language used (I rank) followed by atmosphere to exchange ideas freely with superiors and colleagues (IV rank) and method of communication employed by higher ups (V rank). This might be due to existence of better coordination, mutual trust and understanding between the higher authorities and subordinates in the organization.

\section{Co-ordination}

The results in table 3 revealed that, higher proportion (47.37\%) of the extension personnel of Krishi Vigyan Kendras had medium level of co-ordination. 
Table.1 Over all facilities and resources availability in the extension organizations

\begin{tabular}{|c|c|c|c|c|c|}
\hline \multirow{2}{*}{$\begin{array}{l}\text { Sl. } \\
\text { No. }\end{array}$} & \multirow{2}{*}{ Categories } & \multicolumn{2}{|c|}{ UAS- KVK ( $\left.n_{1}=38\right)$} & \multicolumn{2}{|c|}{ KSDA-RSK $\left(\mathrm{n}_{2}=38\right)$} \\
\hline & & Frequency & Percentage & Frequency & Percentage \\
\hline 1 & Low (Mean $-0.425 * \mathrm{SD})$ & 10 & 26.32 & 16 & 42.11 \\
\hline 2 & Medium (Mean $+0.425 * \mathrm{SD})$ & 20 & 52.63 & 9 & 23.68 \\
\hline \multirow[t]{3}{*}{3} & High $($ Mean $+0.425 * \mathrm{SD})$ & 8 & 21.05 & 13 & 34.21 \\
\hline & Mean & \multicolumn{2}{|c|}{7.18} & \multicolumn{2}{|c|}{5.82} \\
\hline & SD & \multicolumn{2}{|c|}{2.66} & \multicolumn{2}{|c|}{1.37} \\
\hline
\end{tabular}

**Significant at 1 per cent level *Significant at 5 per cent level

Table.2 Facilities and resources provisions for facilitating work in the extension organizations

\begin{tabular}{|l|l|c|c|c|c|}
\hline \multirow{2}{*}{$\begin{array}{l}\text { SI. } \\
\text { No. }\end{array}$} & Facilities and resources & UAS- KVK $\left(\mathbf{n}_{\mathbf{1}}=\mathbf{3 8}\right)$ & \multicolumn{3}{|c}{$\mathrm{KSDA}=76$} \\
\hline $\mathbf{1}$ & Input supplies & Index & Rank & Index & Rank \\
\hline $\mathbf{2}$ & Repairs and maintenance & 56.58 & I & 53.95 & I \\
\hline $\mathbf{3}$ & Transportation / conveyance & 53.68 & V & 43.42 & IV \\
\hline $\mathbf{4}$ & Office supplies & 53.95 & III & 23.68 & V \\
\hline $\mathbf{5}$ & Supply procedure & 47.37 & VI & 47.37 & III \\
\hline $\mathbf{6}$ & Storage facility & 42.11 & VII & 30.00 & II \\
\hline $\mathbf{7}$ & Providing demonstration equipment & 56.58 & I & 42.11 & VI \\
\hline
\end{tabular}

Table.3 Level of communication and co-ordination in extension organizations with other departments/agencies

\begin{tabular}{|c|c|c|c|c|c|}
\hline \multirow{2}{*}{$\begin{array}{l}\text { SL. } \\
\text { No }\end{array}$} & \multirow[t]{2}{*}{ Categories } & \multicolumn{2}{|c|}{ UAS- KVK $\left(n_{1}=38\right)$} & \multicolumn{2}{|c|}{ KSDA-RSK $\left(n_{2}=38\right)$} \\
\hline & & Frequency & Percentage & Frequency & Percentage \\
\hline & Communication & & & & \\
\hline 1 & Low (Mean $-0.425 * \mathrm{SD})$ & 12 & 31.58 & 11 & 28.95 \\
\hline 2 & Medium $($ Mean $\pm 0.425 * S D)$ & 12 & 31.58 & 17 & 44.74 \\
\hline \multirow[t]{4}{*}{3} & High $($ Mean $+0.425 * S D)$ & 14 & 36.84 & 10 & 26.32 \\
\hline & Mean & \multicolumn{2}{|c|}{7.65} & \multicolumn{2}{|c|}{7.81} \\
\hline & SD & \multicolumn{2}{|c|}{2.62} & \multicolumn{2}{|c|}{1.46} \\
\hline & Co-ordination & & & & \\
\hline 1 & Low (Mean $-0.425 * \mathrm{SD})$ & 10 & 26.32 & 9 & 23.68 \\
\hline 2 & Medium $\left(\right.$ Mean $\left.\pm 0.425^{*} \mathrm{SD}\right)$ & 18 & 47.37 & 18 & 47.37 \\
\hline \multirow[t]{6}{*}{3} & High $($ Mean $+0.425 * S D)$ & 10 & 26.32 & 11 & 28.95 \\
\hline & Mean & \multicolumn{2}{|c|}{9.11} & \multicolumn{2}{|c|}{6.58} \\
\hline & SD & \multicolumn{2}{|c|}{2.86} & \multicolumn{2}{|c|}{2.06} \\
\hline & Mann Whitney U test & & & & \\
\hline & Communication & \multicolumn{4}{|c|}{ KVK Vs RSK 0.979} \\
\hline & Co-ordination & \multicolumn{4}{|c|}{ KVK Vs RSK $0.000^{* *}$} \\
\hline
\end{tabular}


Table.4 Level of communication in extension organizations with other departments / agencies

Table.5 Clientele served by the extension organizations

\begin{tabular}{|c|c|c|c|c|c|c|c|}
\hline \multirow{2}{*}{$\begin{array}{l}\text { Sl. } \\
\text { No. }\end{array}$} & \multirow[t]{2}{*}{ Particulars } & \multicolumn{3}{|c|}{ UAS- KVK ( $\left.\mathbf{n}_{1}=38\right)$} & \multicolumn{3}{|c|}{ KSDA-RSK $\left(\mathrm{n}_{2}=38\right)$} \\
\hline & & Mean & Index & Rank & Mean & Index & Rank \\
\hline 1 & Large commercial farmers & 1.13 & 56.58 & VIII & 0.79 & 39.74 & VI \\
\hline 2 & Small/medium-scale commercial farmers & 1.34 & 67.11 & IV & 1.31 & 65.38 & II \\
\hline 3 & Farmers growing specific crops & 1.42 & 71.05 & II & 1.26 & 62.82 & IV \\
\hline 4 & Small-scale subsistence farmers & 1.39 & 69.74 & III & 1.95 & 97.44 & I \\
\hline 5 & Women farmers & 1.28 & 64.47 & V & 1.28 & 64.10 & III \\
\hline 6 & Youth farmers & 1.44 & 72.37 & I & 1.23 & 61.54 & V \\
\hline 7 & Landless agricultural laborers & 1.07 & 53.95 & IX & 0.36 & 17.95 & IX \\
\hline 8 & Rural youth & 1.28 & 64.47 & V & 0.51 & 25.64 & VII \\
\hline \multirow[t]{2}{*}{9} & Rural women (nutrition, health, hygiene) & 1.26 & 63.16 & VII & 0.41 & 20.51 & VIII \\
\hline & Mann - Whitney U test & \multicolumn{6}{|c|}{ KVK Vs RSK $0.000 * *$} \\
\hline
\end{tabular}


Table.6 Different extension functions emphasized by the extension organizations

\begin{tabular}{|c|c|c|c|c|c|c|c|}
\hline \multirow{2}{*}{$\begin{array}{l}\text { Sl. } \\
\text { No. }\end{array}$} & \multirow[t]{2}{*}{ Particulars } & \multicolumn{3}{|c|}{ UAS- KVK ( $\left.\mathbf{n}_{1}=38\right)$} & \multicolumn{3}{|c|}{ KSDA-RSK $\left(\mathbf{n}_{2}=38\right)$} \\
\hline & & $\begin{array}{l}\text { Mean } \\
\text { score }\end{array}$ & Index & Rank & $\begin{array}{l}\text { Mean } \\
\text { score }\end{array}$ & Index & Rank \\
\hline 1 & $\begin{array}{l}\text { Capacity building and empowerment of } \\
\text { farmers }\end{array}$ & 1.82 & 90.79 & II & 1.53 & 76.32 & II \\
\hline 2 & Women and youth empowerment & 1.34 & 67.11 & III & 0.89 & 44.74 & IV \\
\hline 3 & Entrepreneurship development & 1.24 & 61.84 & IV & 0.92 & 46.05 & III \\
\hline 4 & Transfer of technology & 2.00 & 100.00 & I & 1.97 & 98.68 & I \\
\hline 5 & Promotion of products & 1.16 & 57.89 & V & 0.61 & 30.26 & $\mathrm{~V}$ \\
\hline & Mann - Whitney U test & \multicolumn{6}{|c|}{ KVK Vs RSK 0.000** } \\
\hline
\end{tabular}

Similarly, 47.37 per cent of Raita Samparka Kendras extension personal had medium level of co-ordination with other developmental department / agencies. Mann - Whitney U test also showed significant difference between the extension personnel of both the extension organizations. Majority of the extension personnel of Krishi Vigyan Kendras and Raita Samparka Kendras belonged to medium level of co-ordination. This might be due to fact that, the extension organizations are working for the welfare of farming community. In implementation of various schemes and programmes coordination of other related institutes and agencies is very much essential.

Table 4 indicated that, Krishi Vigyan Kendras extension personnel had high level of coordination with Department of Agriculture (I rank), Department of Horticulture (II rank) and NGOs (III rank). The extension personnel of Raita Samparka Kendras had high level of co-ordination with Department of Agriculture (I rank) and Input supply agencies (II rank). High level of co-ordination of extension personnel with department of agriculture is due to fact that, the extension organizations are involved in transfer of latest agricultural technologies to the farming community and department of agriculture is one of the important nodal agencies in the state responsible for carrying out extension activities. Raita Samparka Kendras under Department of agriculture are the grass root organizations working hence they have easy access to farming community and have good coordination with farmers. These might be the probable reasons for the above findings.

\section{Clientele served by the extension organizations}

It was evident from table 5 that, youth farmers (I rank) were the important group of clientele served by the Krishi Vigyan Kendras followed by farmers growing specific crops (II rank), small-scale subsistence farmers (III rank), small/medium-scale commercial farmers (IV rank) and women farmers (V rank). Whereas, small-scale subsistence farmers (I rank) were the important group of clientele served by the Raita Samparka Kendras followed by small/medium-scale commercial farmers (II rank), women farmers (III rank), farmers growing specific crops (IV rank) and youth farmers (V rank). Mann Whitney $U$ test also showed significant difference in clientele served by both the extension organizations. 
It was clear that, organizations primary target group (clientele) reflect the goals of the organization. These results also indicated that, organizations were more specific in terms of their target clientele. Youth farmers with more enthusiasm and energy may adopt the latest agricultural technologies given by the extension organizations like Krishi Vigyan Kendras. Raita Samparka Kendras are working for the benefit of farming community at grass root level may concentrate on small scale subsistence farmers with poor resource base as majority of the farmers in the state and country are small and marginal farmers with small land holdings. These might be the probable reasons for the above results.

Saravanan (2001) reported that private extension service providers mostly concentrate on big farmers, farmers growing commercial crops and areas having favorable environment like high fertile soil. While, Masangano and Mthinda (2012) revealed that, the main target of extension activities of the extension organizations is the smallholder farmer, with 95.80 per cent of organizations spending no time with large commercial farmers. It can be concluded that, the different extension organizations serve different clientele based on their mandated tasks.

\section{Different extension functions emphasized / prioritized by the extension organizations}

It was evident from the results in table 6 that, transfer of technology (I rank) was the important extension function addressed by the extension personnel of Krishi Vigyan Kendras followed by capacity building and empowerment of farmers (II rank), Women and youth empowerment (III) and Entrepreneurship development (IV). In case of Raita Samparka Kendras, transfer of technology (I rank) was the important extension function addressed by the extension personnel followed by capacity building and empowerment of farmers (II rank), Entrepreneurship development (III rank) and Women and youth empowerment (IV rank). Significant difference was observed with respect to different extension functions emphasized by the both the extension organizations (Mann - Whitney U test).

Krishi Vigyan Kendras and Raita Samparka Kendras are the government organizations working under the central and state governments with a mandate of transferring of latest scientific agricultural and allied technology interventions developed at the research stations to the farmers' field to boost up the agricultural production and productivity. These organizations are not profit oriented and working for the welfare of farming community. These could be the probable reasons for the above findings.

Deogratias and Amon (2001) reported that, all-private agribusiness firms are more concerned with enterprise and profit maximization than the empowerment or personal development of the farmer and his/her farm family. Jha et al., (1995) also reported that, private input companies are involved only in the transfer of chemical (fertilizers, pesticides), mechanical and biological (hybrid seeds) technologies developed/produced by them.

It can be concluded from the results of the study that, Majority of the extension personnel in Krishi Vigyan Kendras and Raita Samparka Kendras belonged to medium to low satisfaction category with respect to facilities and resources availability in the organization. Majority of them belonged to high to medium satisfaction category with respect to communication aspects in the organization. Majority of the extension personnel in both the extension organizations belonged to medium level of co-ordination. Youth farmers in case of Krishi Vigyan 
Kendras and small-scale subsistence farmers in case of Raita Samparka Kendras were the important group of clientele targeted. Transfer of technology is the most important extension function emphasized by both extension organizations. Hence, there is a need by the extension organizations to cover larger clientele groups such as women farmers, farmer's cultivation specific crops and others. Extension organizations should emphasize and prioritize capacity building and empowerment of farmers, youth and women empowerment and entrepreneurship development. There is a need to improve the communication within the extension organizations and co-ordination of extension organizations with other extension agencies/department.

\section{References}

Debnath, A. and Saravanan, R., 2014, Job satisfaction and job autonomy of extension personnel of the public agricultural extension organization in Tripura state of north-east India. Int. J. Dev. Res., 4(8): 1643-1650.

Deogratias F. R. and Amon Z. M, 2001, Major agricultural extension providers in Tanzania. African Study Monographs, 22(4): 155-173.
Jha, D., Praduman Kumar, Mruthynjaya, Suresh Pal, Selvarajan, S. and Alka Singh, 1995, Research priorities in Indian agriculture, NCAP Policy Paper No.3, published by Director, NCAP.

Masangano, C. and Mthinda, C., 2012, Pluralistic extension system in Malawi, IFPRI Discussion Paper 01171, UK. Pp34.

Nagananda, C., Bheemappa, A. and Hirevenkangoudar, L.V., 2006, Profile of ADAs and AOs and Organizational Climate in Karnataka State Department of Agriculture. Karnataka J. Agric. Sci., 19(4): 877-882.

Sandika A. L., 2006, A study on organizational climate perception by veterinary officers (VOs) and Veterinary livestock inspectors (VLIs) of department of animal husbandry and veterinary service of Karnataka, $M$. Sc. (Agri.) Thesis, Univ. Agric. Sci., Dharwad, Karnataka (India).

Saravanan, R., 2001, Privatization of agricultural extension. In: Chandra Shekara, P. (Ed), Private extension in India: myths, realities, apprehensions and approaches, National Institute of Agricultural Extension Management, Rajendranagar, Hyderabad - 500 030, A.P. pp 60-71.

\section{How to cite this article:}

Sathish, H.S., D.M. Chandargi and Wali, V.B. 2018. Clientele Served and Extension Functions Emphasized by the Extension Personnel of Extension Organizations. Int.J.Curr.Microbiol.App.Sci. 7(05): 2778-2785. doi: https://doi.org/10.20546/ijcmas.2018.705.323 